\title{
Biology and pathology of urinary tract infections
}

\author{
LÅ HANSON,* A FASTH, $\ddagger$ U JODAL, $\ddagger$ B KAIJSER, † C SVANBORG EDÉN* \\ From the Departments of Clinical Immunology, ${ }^{*}$ and Clinical Bacteriology, $\dagger$ Institute of Medical \\ Microbiology and Department of Pediatrics, $\ddagger$ University of Göteborg, Göteborg, Sweden
}

The normal urinary tract is resistant to colonisation by bacteria. 1 Presence of significant bacteriuria $\left(\geqslant 10^{5}\right.$ bacteria $\left./ \mathrm{ml}\right)$ is, however, not necessarily indicative of an infection of the urinary tract with serious consequences to the host. In fact, urinary tract infections (UTI) should be regarded as a group of infectious diseases of varying clinical severity and prognosis and therefore they demand different levels of priority-that is, for treatment, investigation, including radiology and follow-up. In patients with obstructive malformation UTI is always potentially dangerous and surgical procedures or other radical measures may be required. This review concentrates on the main group of patients with UTI-that is, those without obstructions of the urine flow, or other obvious underlying defects.

In school screening programmes the prevalence of significant bacteriuria is around $1 \%$ in girls. ${ }^{234}$ About $3 \%$ of all girls will have had at least one symptomatic infection before the age of 10 years. ${ }^{2}$ The figures for adult women are similar. In males UTI is less common, but a high frequency is found during the first years of life. ${ }^{2}$

There are two main problems associated with UTI: the first is quantitative. A very large proportion of bacterial infections in our society can be ascribed to UTI. Although the majority of infections are undramatic, a large population suffers from recurrent symptomatic UTI and this makes considerable demands on medical resources. The second problem concerns complications, in that some of these patients suffer renal parenchymal reduction resulting in renal insufficiency and hypertension.

The classical radiological sign of renal damage caused by pyelonephritis is calyceal deformity with reduction of the corresponding parenchyma..$^{5}$ In the epidemiological studies of Winberg et al. ${ }^{2}$ such changes were found in $5 \%$ of $\mathbf{4 4 0}$ girls followed from their first symptomatic UTI. In a group of 156 boys

Accepted for publication 10 December 1980 the frequency of renal scarring was $13 \%$. After follow-up for 8-15 years most of the patients had normal glomerular filtration owing to compensatory hypertrophy of the contralateral kidney. 6 About $10-20 \%$ had bilateral scarring, however, and these patients in particular run the risk of a progressive renal deterioration or the development of hypertension, or both.

\section{Localisation of site of infection}

UTI may be subdivided into three major clinical groups: acute pyelonephritis, acute cystitis, and asymptomatic bacteriuria. Bacteriuria is defined as significant bacteriuria found on screening where the patient was either asymptomatic or showed such discrete symptoms that she or he has not sought medical advice. ${ }^{7}$ In contrast symptomatic UTI is defined on the basis of the symptoms caused and on complementary laboratory tests. ${ }^{8}$ As indicators of an infection involving the kidney (acute pyelonephritis) we have used temperature $>38.5^{\circ} \mathrm{C}$, C-reactive protein $>20 \mathrm{mg} / \mathrm{l}$, microsedimentation rate $>25$ $\mathrm{mm} / \mathrm{h}$, and low renal concentrating capacity during the acute stage of the infection. As diagnostic criteria for acute cystitis we have used dysuria and frequency, temperature not exceeding $38^{\circ} \mathrm{C}$, absence of back and loin pain and normal laboratory tests.

Tests for ascertaining the level of UTI have been much studied especially in view of the limitations of clinical diagnosis. In fact, we have no single foolproof method although ureteric catheterisation may come close to it. However, such a procedure is impracticable. The bladder wash-out test was introduced as a practical simplification and has been widely accepted as a reference method, though unsupported by any studies of reliability. We used a range of tests in girls with symptomatic UTI. ${ }^{8}$ Intermittent discharge of bacteria into the renal pelvis was a frequent finding and probably accounted for an inadequate sensitivity of the bladder wash-out 
test. In fact, the non-specific $\mathrm{C}$-reactive protein (CRP) concentration was the best indicator of renal involvement when compared to the overall results from the range of tests. The usefulness of the CRP test has been confirmed by others. ${ }^{9}$ In our routine work-up of the children with symptomatic UTI we therefore include determination of CRP concentrations as well as of renal concentrating capacity.

Determination of serum antibodies to the $\mathrm{O}$ antigen of the infecting Escherichia coli has enabled the distinction to be drawn between acute pyelonephritis and acute cystitis. ${ }^{1011}$ The large number of $\mathrm{O}$-antigens with a limited number of cross-reactions makes this method impracticable. With a pool of antigens for routine titrations the sensitivity of the method decreases. 8 The detection of antibodycoated bacteria has been used as an indicator of renal infection. ${ }^{1213}$ In children, however, the sensitivity was found to be low. ${ }^{814} 15$ Recently, the reliability of the antibody-coated bacteria method for level diagnosis in adults has also been questioned. ${ }^{16}$ Finally, two chemical methods should be mentioned: it has been shown that the amounts of lactic dehydrogenase isoenzyme $5^{17}$ and of $\beta 2$-microglobulin $^{18}$ are raised in the urine of patients with acute pyelonephritis.

\section{VIRULENCE FACTORS IN GRAM-NEGATIVE BACTERIA CAUSING UTI}

Differences between bacteria populations may explain the variable severity of UTI in the patient. Firstly, of the $E$ coli bacteria causing acute pyelonephritis $80 \%$ belonged to only eight common $O$ antigen groups. In contrast, of the $E$ coli strains causing asymptomatic bacteriuria, $45 \%$ had an incomplete lipopolysaccharide (endotoxin) of the cell membrane and were spontaneously agglutinating. The frequency of spontaneously agglutinating bacteria in the urine of asymptomatic bacteriuria patients was even higher than that in the stool of healthy age-matched children. 1920

Secondly, the polysaccharide capsules of $E$ coli are important virulence factors.21 Five different $\mathrm{K}$-antigens account for about $70 \%$ of $E$ coli causing acute pyelonephritis in children. The $\mathrm{K} 1$ antigen was found on $39 \%$ of the urinary isolates. ${ }^{22}$

Thirdly, the bacteria causing acute pyelonephritis were more resistant to the bactericidal activity of normal serum than were bacteria found in asymptomatic bacteriuria patients. ${ }^{23}$ The latter strains were even more sensitive than the ones found in normal stool.

Fourthly, $E$ coli causing acute pyelonephritis attached efficiently to epithelial cells from the urinary tract in contrast to $E$ coli from asymptomatic bacteriuria patients, the majority of which
Hanson, Fasth, Jodal, Kaijser, Svanborg Edén attached poorly or not at all. ${ }^{24}{ }^{25}$ The species and tissue $\frac{0^{*}}{\vec{\sigma}}$ specificity observed in the attachment of $E$ coli in UTI patients indicates that adhesion is due not to a $\overrightarrow{\overline{\mathrm{C}}}$ "general stickiness" of the bacterium, but to a $\frac{\text { }}{0}$ specific interaction of bacterial surface ligands"adhesins"-with receptors in the epithelial cell $\frac{\bar{\sigma}}{\bar{*}}$ surface. ${ }^{26}$ The bacterial structures involved in $\vec{\nabla}$ attachment to epithelial cells have been classified $\cong$ according to the ability of bacteria to bind to other $\infty$ cells-for example, erythrocytes. ${ }^{27}$ Two main groups $\vec{\circ}$ of adhesins are found on $E$ coli causing UTI. ${ }^{26}$ One $\overrightarrow{-}$ group induces agglutination of erythrocytes; reversed $\vec{\omega}_{\vec{\omega}}$ in the presence of D-mannose. These adhesins are found on most enterobacteria without any obvious? relation to virulence. $E$ coli strains carrying only these $\stackrel{\omega}{\oplus}$ adhesins attach poorly to human uroepithelial cells. $\overrightarrow{-}$ but bind to urinary slime-that is, Tamm-Horsfall of protein. ${ }^{28} 29$ The second group of adhesins induce agglutination of human erythrocytes, but this group is not affected by D-mannose. $E$ coli bacteria carrying $\vec{C}$ these adhesins attach to human uroepithelial cells and are commonly found in patients with acute $\vec{\ominus}$

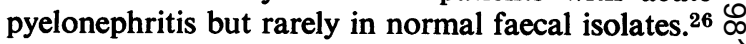
Both types of adhesins can be of a pilus or fimbriate nature, ${ }^{2630}$ but the existence of non-fimbriate adhesins has also been suggested. ${ }^{27}$

We recently reported that glycolipids isolated from human urinary tract epithelial cells inhibit the $\stackrel{0}{\circ}$ attachment of $E$ coli to uroepithelial cells from the $\stackrel{\square}{\varrho}$ same donor. ${ }^{31}$ Globoseries glycolipids, especially $\overrightarrow{\overrightarrow{0}}$ globoside, fulfil the criteria of a receptor. ${ }^{25}$ The 3 binding reaction, however, is complex and isolated $\underset{F}{F}$ pili only partly satisfy the receptor. The density or nature of receptors may explain why $E$ coli bind more efficiently to uroepithelial cells from patients with recurrent UTI than from individuals without UTI. ${ }^{33-35}$

These various bacterial properties are commonly found in $E$ coli causing acute pyelonephritis, but less often in asymptomatic bacteriuria strains; they are likely to be virulence factors, necessary for the $\frac{7}{0}$ bacteria to manifest the infection. In contrast, Proteus mirabilis rarely causes UTI in persons with of normal urinary tracts. $P$ mirabilis differs from $E$ coli $N$ in bacterial virulence factors. No polysaccharide $N$ capsule has been described and $P$ mirabilis also differ from $E$ coli in their capacity to attach to human uroepithelial cells. ${ }^{36}$ From patients with $\stackrel{\varrho}{=}$ UTI, $P$ mirabilis attached to the same extent as $\stackrel{\mathbb{P}}{+}$ $P$ mirabilis from other sources such as the stools of healthy carriers or blood of cases with septicaemia. The $\boldsymbol{P}$ mirabilis strains did not attach to transitional $\underset{\mathbb{D}}{\stackrel{D}{ }}$ epithelium from the bladder but to the squamous $\frac{\rho}{\Phi}$ epithelium from the outer genital region. ${ }^{36}$ In addi- $\cong$ tion the attachment was more striking in the midmenstrual period. The inability of $\boldsymbol{P}$ mirabilis to 8 
attach to the bladder epithelium may explain its lower virulence compared to $E$ coli.

\section{HOST RESPONSE IN UTI}

As in most infections the host defence is activated in response to an attack of UTI. During acute pyelonephritis there is a systemic antibody response. Antibodies against the $\mathrm{O}$-antigen ${ }^{810}$ and occasionally the $\mathrm{K}$-antigen ${ }^{21}$ of the infecting strain have been found and recently antibodies to type 1 fimbriae were described. ${ }^{37}$ A local antibody response consisting of IgG and secretory IgA antibodies can be detected in the urine. ${ }^{38}$ Antibodies to fimbriae have not so far been found in the urine. Antibodies against several bacterial structures-for example, the $\mathrm{O}$-antigen or $\mathrm{K}$-antigen, can protect against haematogenous or ascending pyelonephritis in experimental animals. ${ }^{39} 40$ The antibodies may be of value for the patient either to limit the damage incurred in the course of an infection or to prevent colonisation preceding recurrence. Antibodies in combination with the wash-out effect of the urine may prevent colonisation of the urinary tract.

In patients with many recurrent infections it may be possible to induce a protective immune response by vaccination, as described in animals. ${ }^{39} 40$ Immunisation could be especially useful for the group who risk renal damage. Such a vaccine should presumably contain a broad selection of antigens including the fimbriae and polysaccharide capsule antigens most commonly found among bacteria causing UTI.

\section{RISK GROUP OF UTI PATIENTS}

In our prospective follow-up studies few patients have developed renal parenchymal reduction, possibly because of close supervision and immediate treatment of each symptomatic infection. ${ }^{2}$ Renal damage that does occur is related to febrile UTI among those patients ${ }^{41}$ but in the individual case prediction is often difficult. The early attacks of UTI are more often symptomatic than the recurrences which are "asymptomatic" in about $60 \%{ }^{42}$ No clinical or laboratory criteria have so far been useful to predict those cases which are to develop renal scarring.

Development of renal scarring is related to vesicoureteric reflux shown by voiding cystourethrography. The risk has been found especially high with dilatation of the refluxing renal unit. ${ }^{43}$ The matter is complex, however, and in our material scarring has occurred with low-grade reflux and even with no demonstrable reflux. In addition, reflux has a considerable tendency to disappear during follow-up. ${ }^{44}$

In identifying patients at risk, some observations on antibodies against the Tamm-Horsfall urinary glycoprotein are of considerable interest. Patients with acute bacterial pyelonephritis, but not those with acute cystitis, had increasing IgG and $\operatorname{IgA}$ antibody concentrations against Tamm-Horsfall protein during the course of the infection, reaching levels well above healthy controls. ${ }^{45}$ The most marked increase and the highest concentrations were in serum from patients with vesicoureteric reflux. Interestingly, the patients with renal damage and acute pyelonephritis had a poor response, with almost no antibody increase in those with the most severe renal damage (as judged from serum creatinine and glomerular filtration rate). 4647 After the infection, the IgG antibody concentrations of the patients with scarred kidneys fell below the range of the controls and compared to pyelonephritis patients with normal urography, there was no overlapping between the IgG antibody values. The measurement of IgG antibodies against Tamm-Horsfall protein could become a risk group test for the early detection of renal damage.

The rise of autoantibodies against the TammHorsfall protein occurs in almost every case of acute pyelonephritis caused by various $E$ coli and Proteus strains. This observation together with the discovery that all above the age of eight to nine months have such autoantibodies, ${ }^{45}$ suggest the possibility of a cross-reaction between the Tamm-Horsfall protein and Gram-negative bacteria. In fact we found such a cross-reaction between the Tamm-Horsfall protein and a protein from Gram-negative bacteria. ${ }^{48}$ Antibody production might be induced by the cross-reacting antigens of colonising intestinal Gram-negative bacteria. This may account for the presence of autoantibodies against the TammHorsfall protein found in all humans. The boost of this antibody response occurring during acute pyelonephritis may be due to the increased exposure of the Tamm-Horsfall protein to the immune system during the parenchymal infection, or to an increase in cross-reacting bacterial antigen.

It is tempting to suggest that the development of renal damage associated with bacterial pyelonephritis is related to autoimmunity to TammHorsfall protein. In some cases of tubulointerstitial disorders, deposits of Tamm-Horsfall protein have been found in the interstitial tissue. ${ }^{49-51}$ These lumps were occasionally surrounded by inflammatory cells and in an experimental model the extent of these deposits was correlated to the concentration of antibodies against Tamm-Horsfall protein. ${ }^{52}$ The low antibody concentration found in patients with renal damage might be due to absorption of the antibodies in the interstitial infiltrates, or perhaps to an immunosuppressive effect of released tubular antigens as shown in experimental systems. ${ }^{53}$ 
The Tamm-Horsfall protein might also have other influences on UTI as the protein can bind $E$ coli in the urinary tract. ${ }^{29}$ The Tamm-Horsfall protein or urinary slime may act as a non-specific defender against Gram-negative bacterial infection of the bladder and kidney by preventing attachment to the epithelial surface. To overcome this barrier bacteria may have developed the mannose-resistant tissuebinding type of fimbriae which are associated with acute pyelonephritis strains. On the other hand, binding to Tamm-Horsfall protein may facilitate colonisation of the urinary tract of strains lacking the tissue-binding capacity. This may explain why $E$ coli strains unable to attach to the urinary tract mucosa, persist for a long time in the urine of girls with asymptomatic bacteriuria, without underlying defects like residual urine.

\section{ASYMPTOMATIC BACTERIURIA}

The bacteria found in patients with asymptomatic bacteriuria lack certain properties found in $E$ coli causing symptomatic UTI. In some patients the bacteria changed to less virulent forms during longterm follow-up without treatment. ${ }^{54}$ Providing the kidneys were normal at the first radiological investigation, non-treatment of girls with asymptomatic bacteriuria did not lead to deterioration of the kidneys during a three-year follow-up. The only patient who developed renal scarring had an attack of acute pyelonephritis due to a new strain, distinct from the asymptomatic bacteriuria strain. ${ }^{55}$

Treatment of girls with asymptomatic bacteriuria eradicated the bacteria rapidly in $98 \%$ of the cases. In $48 \%$ asymptomatic bacteriuria recurred at least once, and in $22 \%$ it recurred repeatedly. In some cases elimination of the low virulence bacteria allowed a "recurrence" caused by a more virulent strain originating from the stools leading to an attack of acute pyelonephritis. This was seen especially in girls with renal damage. In the untreated group about $10 \%$ lost the bacteria each year. After five years the incidence of bacteriuria was similar in the treated and non-treated girls.

On the basis of our follow-up studies in children it seems that treatment of girls with a radiologically normal urinary tract is often unnecessary and sometimes even harmful. Criteria of bacterial virulence such as the capacity to attach to uroepithelial cells or presence of capsular substance especially $E$ coli $\mathrm{K} 1$ may prove valuable in deciding whether to treat or not. It must be remembered, however, that patients at risk, such as those with established renal scarring, may be "compromised hosts" with an increased sensitivity to bacteria carrying few virulence factors. In such patients all episodes of bacteriuria should be treated.

\section{Conclusions}

Combinations of several virulence factors are found $\overrightarrow{\vec{F}}$ on most $E$ coli bacteria causing acute pyelonephritis, $\vec{\square}$ but rarely on bacteria isolated from the normal등 intestinal flora. Examples of virulence factors are: $\overline{\bar{c}}$ capacity to attach to uroepithelial cells, presence of $\vec{\phi}$ endotoxin, and presence of polysaccharide capsules. $\stackrel{\circ}{\nu}$ The host defence system against these bacterial ${ }^{\text {क }}$ components protects against pyelonephritis in $\overrightarrow{0}$ experimental models. Induction of protective immunity through vaccination may also be possible in the human and be of special value to the group at risk who are susceptible to renal scarring after kidney ${ }_{\omega}$ infections.

Symptomatic UTI in children may be separated into acute pyelonephritis and acute cystitis. Evalu- 0 ation of the clinical symptoms together with deter-o mination of the non-specific C-reactive protein concentration and renal concentrating capacity are, $\subset$ in our opinion, the best indicators of renal infection. The risk of renal scarring is related to the number of $\vec{\theta}$ attacks of acute pyelonephritis. Analysis of anti- $\infty$ bodies against Tamm-Horsfall protein is a useful ${ }^{-}$ indicator of the risk of renal scarring, since high antibody concentrations during infection are asso-s ciated with vesicoureteric reflux and low antibody concentrations and a poor antibody response during $\frac{\varnothing}{\varnothing}$ an attack of acute pyelonephritis are associated with $\varrho$ renal damage. In girls with significant bacteriuria $\overrightarrow{\vec{O}}$ without symptoms, diagnosis of severity is difficult. 3 Asymptomatic bacteriuria may, however, be left untreated in patients with radiologically normal urinary tracts without an increased risk of renal홍 scarring.

These studies were supported by grants from the Swedish Medical Research Council, Board for 3 Technical Development (project No. EKB-U-614), 은 the Ellen, Walter and Lennart Hesselman Foundation for Scientific Research and Stiftung Volkswagenwerk, W Germany. This review was written during the tenure of a Fogarty Scholarship-inResidence at the National Institute of Health, USA N for Lars Hanson between August 1979 and September $\underset{\omega}{~}$ 1980.

\section{References}

1 Cox C, Hinman F. Experiments with induced bacteriuria, vesical emptying and bacterial growth on the mechanism of bladder defense to infection. $J$ Urol 1969;86:739-48. 우

2 Winberg J, Anderson HJ, Bergström T, et al. Epidemiology of symptomatic urinary tract infection in childhood. $\frac{\mathbb{D}}{\mathbb{Q}}$ Acta Paediatr 1974;Suppl 252.

${ }^{3}$ Kass EH, Zinner SH. Bacteriuria and renal disease. $J \underset{<}{\sigma}$ Infect Dis 1969;120:27-46.

Kunin CM, Deutscher R, Paquin A. Urinary tract infection 
in school children: An epidemiologic, clinical, and laboratory study. Medicine 1964;43:91-130.

- Hodson CJ, Wilson S. Natural history of chronic pyelonephritic scarring. Br Med J 1965;ii:171-94.

- Winberg J, Claesson I, Jacobsson B, Jodal U, Peterson H. Renal growth after acute pyelonephritis in childhood. An epidemiological approach. In: Hodson CJ, Kincaid-Smith P, eds. Reflux nephropathy. New York: Masson, 1979;309-22.

7 Lindberg U, Claesson I, Hanson LA, Jodal U. Asymptomatic bacteriuria in schoolgirls. I. Clinical and laboratory finding. Acta Paediatr Scand 1975;64:425-31.

8 Jodal $U$, Lindberg $U$, Lincoln $K$. Level diagnosis of symptomatic urinary tract infections in childhood. Acta Paediatr Scand 1975;64:201-8.

- Wientzen RL, McCracken GH, Petruska ML, Swinson SG, Kaijser B, Hanson L $\AA$. Localization and therapy of urinary tract infections of childhood. Pediatrics 1979; 63:467-74.

10 Winberg J, Anderson HJ, Hanson LA,, Lincoln K. Studies of urinary tract infections in infancy and childhood. $\mathbf{I}$. Antibody response in different types of urinary tract infections caused by coliform bacteria. Br Med J 1963; ii:524-7.

11 Vosti KL, Monto AS, Rantz LA. Host-parasite interaction in patients with infections due to Escherichia coli. II. Serologic response of the host. J Lab Clin Med 1965;66: 613-26.

12 Jones SR, Smith JW, Sanford JP. Localization of urinarytract infections by detection of antibody-coated bacteria in urine sediment. $N$ Engl J Med 1974;290:591-3.

13 Thomas V, Shelokov A, Forland M. Antibody-coated bacteria in the urine and the site of urinary-tract infection. $N$ Engl J Med 1974;290:588-91.

14 Forsum U, Hjelm E, Jonsell G. Antibody-coated bacteria in the urine of children with urinary tract infections. Acta Paediatr Scand 1976;65:639-42.

15 Hellerstein S, Kennedy E, Nussbaum L, Rice K. Localization of the site of urinary tract infections by means of antibody-coated bacteria in the urinary sediments. $J$ Pediatr 1978;92:188-93.

16 Mundt KA, Polk BF. Identification of site of urinary-tract infections by antibody-coated bacteria assay. Lancet 1979;ii:1172-5.

17 Carvajal HF, Passey RB, Berger M, Travis LB, Lorentz WB. Urinary lactic dehydrogenase isoenzyme 5 in the differential diagnosis of kidney and bladder infections. Kidney Int 1975;8:176-84.

18 Schardijn G, Statius van Eps LW, Swaak AJG. Urinary beta ${ }_{2}$-microglobulin in upper and lower urinary-tract infections. Lancet $1979 ; \mathrm{i}: 805-7$

19 Lindberg U, Jodal U, Hanson LÅ, Kaijser B. Asymptomatic bacteriuria in schoolgirls. IV. Difficulties of level diagnosis and the possible relation to the character of infecting bacteria. Acta Paediatr Scand 1975;64:574-80.

${ }^{20}$ Lidin-Janson G, Lindberg U. Asymptomatic bacteriuria in schoolgirls. VI. The correlation between urinary and faecal Escherichia coli. Relation to the duration of the bacteriuria and the sampling technique. Acta Paediatr Scand 1977;66:349-54.

${ }^{21}$ Kaijser B, Vahlne G. Escherichia coli $\mathrm{K}$ antigen. Zbl Bakt Hyg I Abt Orig A 1979;243:271-88.

${ }^{22}$ Kaijser B, Hanson L $\AA$, Jodal U, Lidin-Janson G, Robbins JB. Frequency of $E$ coli $\mathrm{K}$ antigens in urinary tract infections in children. Lancet $1977 ; \mathrm{i}: 663-4$.

${ }^{23}$ Lidin-Janson G, Hanson LA, Kaijser B, Lincoln K, Lindberg U, Olling S, Wedel H. Comparison of Escherichia coli from bacteriuric patients with those from feces of healthy schoolchildren. J Infect Dis 1977;136:346-53.

24 Svanborg Edén C, Hanson LÁ, Jodal U, Lindberg U,
Sohl Åkerlund A. Variable adhesion to normal human urinary tract epithelial cells of Escherichia coli strains associated with various forms of urinary tract infections. Lancet 1977; ii:790-2.

${ }^{25}$ Svanborg Edén C, Eriksson B, Hanson LA, Jodal U, Kaijser B, Lidin-Janson G, Lindberg U, Olling S. Adhesion to normal human uro-epithelial cells of Escherichia coli from children with various forms of urinary tract infections. J Pediatr 1978;93:398-403.

${ }^{26}$ Svanborg Edén C, Hagberg L, Hanson LA, Korhonen T, Leffler $\mathrm{H}$, Olling S. Adhesion of Escherichia coli in urinary tract infection. In: Adhesion and Microorganism Pathogenicity. (Ciba Found Symp 80) London: Pitman Medical (in press).

27 Duguid JP. The function of bacterial fimbriae. Arch Immunol Ther Exp 1968;16:173-88.

${ }^{28}$ Ørskov I, Ørskov F, Birch-Andersen A. Comparison of Escherichia coli fimbrial antigen F7 with type 1 fimbriae. Infect Immun 1980;27:657-66.

29 Fasth A, Hanson LA, Svanborg Edén C. Tamm-Horsfall glycoprotein that associates with Escherichia coli may inhibit attachment to human urinary tract epithelial cells in vitro. FEMS Microbiol Lett (submitted).

${ }^{30}$ Korhonen T, Edén S, Svanborg Edén C. Binding of purified Escherichia coli pili to human urinary tract epithelial cells. FEMS Microbiol Lett 1980;7:237-41.

${ }^{31}$ Svanborg Edén C, Leffler H. Glycosphingolipids as possible receptors for Escherichia coli attaching to human urinary sediment epithelial cells. Scand J Infect Dis 1980; Suppl 24:144-7.

32 Leffler H, Svanborg Edén C. Chemical identification of a glycosphingolipid receptor for Escherichia coli attaching to human urinary tract epithelial cells and agglutinating human erythrocytes. FEMS Microbiol Lett 1980;8: 127-34.

${ }^{33}$ Fowler JE, Stamey TA. Studies of introital colonization in women with recurrent urinary infections. VII. The role of bacterial adherence. J Urol 1977 ;ii:472-6.

34 Källenius G, Winberg J. Bacterial adherence to periureteral epithelial cells in girls prone to urinary tract infections. Lancet 1978 ;ii :510.

${ }^{35}$ Svanborg Edén C, Jodal U. Attachment of Escherichia coli to sediment epithelial cells from UTI prone and healthy children. Infect Immun 1979;26:837-40.

36 Svanborg Edén C, Larsson P, Lomberg H. Attachment of Proteus mirabilis bacteria to human urinary tract epithelial cells is different from that of Escherichia coli. Infect Immun 1980;27:804-7.

37 Silverblatt F, Rene P. Serologic response to $E$ coli pili in pyelonephritis. Abstract ICAAC Boston, 1979.

${ }^{38}$ Sohl Åkerlund A, Ahlstedt S, Hanson LA, Jodal U. Antibody responses in urine and serum against Escherichia coli $\mathrm{O}$ antigen in childhood urinary tract infection. Acta Pathol Microbiol Sect C 1979;87:29-36.

39 Kaijser B, Larsson P, Olling S. Protection against ascending $E$ coli pyelonephritis in rats and significance of local immunity. Infect Immun 1978;20:78-81.

${ }^{40}$ Kaijser B, Larsson P, Schneerson R. Protection against acute, ascending pyelonephritis caused by $E$ coli in rats using isolated capsular antigen conjugated to bovine serum albumin (in manuscript).

11 Jodal U, Bjure J, Claesson I, Hanson LA, Jacobsson B, Lindberg U, Peterson $H$, Winberg $J$. Häufigkeit von Rezidiven und von Nierenparenchymnarben-Verleich von Mädchen mit symptomatischer Harnwegsinfektion und asymptomatischer Bacteriurie. In: Olbing $\mathbf{H}$, ed. Rezidivierende nicht-obstructive Harnwegsinfektionen bei Kindern. Berlin: Springer Verlag, 1980;11-20.

42 Bergström T. A prospective study of urinary tract infection in infancy and childhood. Thesis, Göteborg, 1972. 
${ }^{43}$ Rolleston GL, Shannon FT, Otley WLF. Follow-up of vesico-ureteric reflux in the newborn. Kidney Int 1975; 8:559-64.

${ }^{44}$ Edwards D, Norman ICS, Prescod N, Smellie JM. Disappearance of vesicoureteric reflux during long-term prophylaxis of urinary tract infection in children. $\mathrm{Br} \mathrm{Med}$ $J$ 1977; ii :285-8.

45 Fasth A, Hanson LÅ, Jodal U, Peterson H. Autoantibodies to Tamm-Horsfall protein associated with urinary tract infections in girls. J Pediatrics 1979;95:54-60.

46 Fasth A, Bengtson U, Kaijser B, Wieslander J. Antibodies to Tamm-Horsfall protein associated with kidney scarring and urinary tract infections in adults. Kidney Int 1981 ; (in press).

47 Fasth A, Bjure J, Hellström M, Jacobsson B, Jodal U. Autoantibodies to Tamm-Horsfall glycoprotein in children with renal damage associated with urinary tract infections. Acta Paediatr Scand 1980;69:709-15.

48 Fasth A, Ahlstedt S, Hanson LA, Jann B, Jann K, Kaijser B. Cross-reactions between the Tamm-Horsfall glycoprotein and Escherichia coli. Int Archs Allergy appl Immunol 1980;63:303-11.

49 Resnick JS, Sisson S, Vernier RL. Tamm-Horsfall protein. Abnormal localization in renal disease. Lab Invest 1978; 38:550-5.
${ }^{50}$ Solez K, Heptinstall RH. Intrarenal urinary extravasation with formation of venous polyps containing Tamm- 음 Horsfall protein. J Urol 1975;119:180-3.

51 Zager RA, Cotran RS, Hoyer JR. Pathologic localization $\overline{\overline{\vec{N}}}$ of Tamm-Horsfall protein in interstitial deposits in renal disease. Lab Invest 1978;38:52-7.

${ }^{52}$ Hoyer JR. Tubulointerstitial complex nephritis in rats immunized with Tamm-Horsfall protein. Kidney Int $\frac{\bar{\Phi}}{\partial}$ 1980;17:284-92.

${ }^{53}$ Neilson EG, Phillips SM. Cell mediated immunity in interstitial nephritis. J Immunol 1979;123:2373-80.

${ }^{54}$ Lindblad BS, Ekengren $\mathrm{K}$. The long term prognosis of $\vec{\circ}$ non-obstructive urinary tract infection in infancy and. childhood after the advent of sulphonamides. Acta Paediatr Scand 1969;58:25-32.

${ }^{55}$ Lindberg U, Claesson I, Hanson LÅ, Jodal U. Asymptomatic bacteriuria in schoolgirls. VIII. Clinical course during a 3-year follow-up. J Pediatr 1978;92:194-9.

Requests for reprints to: Dr LÅ Hanson, Department of 0 Clinical Immunology, University of Göteborg, Guidhedsgatan 10, S413 46 Göteborg, Sweden. 